（昭 和 34 , 年 2 月 20 日 受 理)

\title{
チオール酸エステルのラネーニッケルによる 脱硫還元分解（第 1 報）
}

\author{
Reductive Desulfurization of Thiolacid Esters by Raney Nickel. I
}

高級脂肪族チオール酸エステルについで*

Studies on the higher aliphatic thiolacid esters

\section{奥 村 重 雄 ${ }^{* *}$. 増 村 光 雄 ${ }^{* *}$. 堀 江 德 愛 ${ }^{* *}$ Shigeo OKUMURa Mitsuo Masumura Tokunaru Horie}

The formation of alcohols from catalytic desulfurization decomposition of thiol ethyl esters or thiol benzyl esters of caprylic, capric, lauric and stearic acids has been investigated. In these cases, aldehydes are formed as intermediate products by regulating the conditions for reaction. The best yield of aldehyde in this experiment was obtained by reacting $10 \mathrm{~g}$. Raney nickel for 0.009 mole of the thiol ester for 2 hours at room temperature. Also, the effect of ester group on the formation of aldehyde has been investigated and it was found that the yield of aldehyde was $10 \%$ higher in thiol ethyl ester than thiol benzyl ester.

カルボキシル基の還元法の一つとしてチオール酸エス テルをラネーニッケルで還元する脱硫還元介解法 ${ }^{1)} か ゙$ 知 られている。これは J. Bougault $\left.{ }^{2}\right)$ らがチオール酢酸 ナトリウムよりアセトアルデヒドを得たととに始まり， その後 Jeger ${ }^{3)}$ らおよび Wolfrom ${ }^{4}$ らとよりそれぞれ 独立的に各種チオール酸エステルにつき検討が加えら れ，前者はチオールを酸エステルを無水溶媒中常温常圧 で還元してアルコール得ているが，後者は含水アルコ ール中で還元してアルデヒドを得たと報告している。ま た Levin ${ }^{51}$ らとより活性なラネーニッケルを用いると 大部分アルコールを生ずるが，アセトン中で加熱処理し て活性度を低下させたラネーニッケルを用いてアルデヒ トの収量を高められることが明らかにされた。

そこでわれわれはこれらのアルコールおよびアルデヒ ドの生成過程を推測する目的で各種高級脂肪族チオール 酸エステルの活性ラネーニッケルによる還元分解条件に ついて検討し次のような結果を得た。

\section{I.アルコールの生成条件}

この脱硫還元分解はラネーニッケル量, 反応時間, 反 * 昭和 29 年 7 月 (1954) 日本化学会中国四国支部高知地 方大会護演

**徳島大学工学部応用化学教室（徳島市南常三島町 2)
表 1 ラウリン酸チオールベンジルエステルの脱硫 還元分解

\begin{tabular}{|c|c|c|c|c|}
\hline \multirow{2}{*}{$\begin{array}{c}\text { 反応時間 } \\
\text { (min) }\end{array}$} & \multirow{2}{*}{$\begin{array}{c}\text { 反応温度 } \\
\left({ }^{\circ} \mathrm{C}\right)\end{array}$} & \multicolumn{2}{|c|}{ 生成物収率 (\%) } & \multirow{2}{*}{$\begin{array}{c}\text { 未反応物 } \\
(\%)\end{array}$} \\
\hline & & アルデヒド & アルコール & \\
\hline $\begin{array}{c}2 \sim 3 \\
5 \sim 7 \\
20 \sim 23 \\
60 \\
120\end{array}$ & $\begin{array}{c}30 \sim 35 \\
\text { " } \\
\text { "I } \\
\text { "I } \\
\prime \prime\end{array}$ & $\begin{array}{r}10.5 \\
11.5 \\
1.5 \\
- \\
-\end{array}$ & $\begin{array}{l}36 \\
38 \\
78 \\
83 \\
\text { "I }\end{array}$ & $\begin{array}{l}24 \\
19 \\
- \\
-\end{array}$ \\
\hline
\end{tabular}

ラネーニッケル $20 \mathrm{~g}$, 浴媒アルコール(濃度 $90 \%)$, チオールエステ 几 $0.009 \mathrm{~mol}$

表 2 ラウリン酸チオールベンジルエステルの脱硫 還元分解

\begin{tabular}{|c|c|c|c|}
\hline \multirow{2}{*}{$\begin{array}{l}\text { 溶媒アルコー } \\
\text { ル濃度 }(\%)\end{array}$} & \multirow{2}{*}{$\begin{array}{c}\text { 反応温度 } \\
\left({ }^{\circ} \mathrm{C}\right)\end{array}$} & \multicolumn{2}{|c|}{ 生成物収率 $(\%)$} \\
\hline & & アルデヒド & アルコール \\
\hline 100 & $20 \sim 30$ & - & 85 \\
\hline 95 & $5 \sim 10$ & - & \\
\hline " & $-5 \sim-10$ 社 & - & 82.5 \\
\hline 90 & $30 \sim 35$ & 一 & 83 \\
\hline$" 1$ & $3 \sim 6$ & - & 82.5 \\
\hline 80 & $30 \sim 35$ & - & $" \prime$ \\
\hline " & 還 流 & - & " \\
\hline
\end{tabular}

ラネーニックル $20 \mathrm{~g}$, 反応時間 $2 \mathrm{hr}$, チオールエステル $0.009 \mathrm{~mol}$

〔注〕この温度にてチオールエステルは溶媒に不溶であるがそのままか くはん下 8 hr 反応させた。 
表 3 各種高級脂肪酸チオールエステルの脱硫還元分解

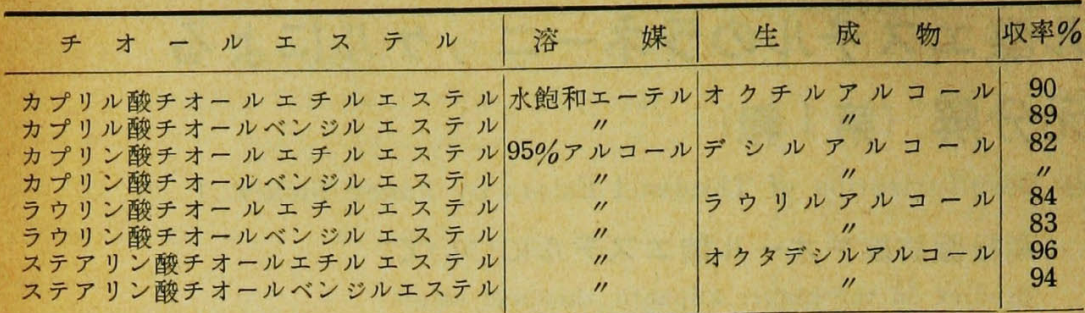

ラネーニッケル $20 \mathrm{~g}$, 反応時間 $2 \mathrm{hr}$, 反応温度 $25 \sim 35^{\circ} \mathrm{C}$, チオールエステル $0.009 \mathrm{~mol}$ 。
脂肪酸チオールエステル の還元分解にてアルデヒ ドを得るには含水溶媒を 用いることを報告してい る。われわれはラウリン 酸チオールベンジルエス テルおよびエチルエステ ルとついて前記アルコー ルの生成条件よりラネー
応温度拈よび溶媒の含水度にも関係すると考えられる ${ }^{2,3}$ ので十分量のラネーニッケルをを用いて他の条件につい て検討した結果を表 1〜3 と示した。

考察 表1によれば十分量のラネーニッケルを使 用しても反応時間が不足すればアルコール以外にアルデ ヒドを副生し未反応物も残る。これよりして反応初期に アルデヒドが生ずることが推測される。また表 2 ，表 3 によればラネーニッケル量および反応時間が十分であれ ば溶媒の含水度(ただし80〜100\%アルコールの範囲内に

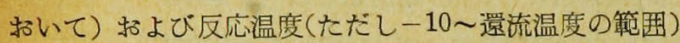
には無関係に高収率にて アルコールを得る。この 実験範囲内におけるアル コール生成の最適条件は チオールエステル 0.009 mol に対しラネーニッケ ル $20 \mathrm{~g}$, 反応時間 $2 \mathrm{hr}$ で ある。

\section{II. アルデヒドの 生成}

Wolfrom $5^{4)}$ は低級
ニッケルの量を減じて検討した結果を 表 4 と示した。

考 察 これによればラネーニッケルの使用量が減 ずるにしたがって還元生成物中のアルデヒドの量が増大 するが未反応物も同時に増加し，また同一条件において は溶媒の含水度の高い場合にアルデヒドの収率が高く， 同一条件に招いてはベンジルエステルよりもエチルエス テルの方がアルデヒドの収率が高くなる傾向がみられ る。この範囲内におけるアルデヒドの生成最適条件はチ オール酸エステル $0.009 \mathrm{~mol}$ に対してラネーニッケル $10 \mathrm{~g}$, 溶媒は $80 \%$ アルコール, 室温, $2 \mathrm{hr}$ であり,こ 表 5 チオールエステルの脱硫還元分解

\begin{tabular}{|c|c|c|c|c|}
\hline \multirow{2}{*}{ チ オ } & \multirow{2}{*}{$\begin{array}{l}\text { 溶媒アル } \\
コ ー ル \text { 濃 } \\
\text { 度 }(\%)\end{array}$} & \multicolumn{2}{|c|}{ 生成物収率 $(\%)$} & \multirow{2}{*}{$\begin{array}{c}\text { 未反応物 } \\
(\%)\end{array}$} \\
\hline & & アルデヒド & アルコール & \\
\hline カプリル酸チオールエチルエステル & 80 & 37 & 38 & - \\
\hline カプリル酸チオールベンジルエステル & "I & 23 & 41 & 10 \\
\hline カプリン酸チオールエチルエステル & "I & 37.5 & 42 & $\overline{7}$ \\
\hline カプリン酸チオールペンジルエステル & " & 23 & 50 & 7 \\
\hline ラウリン酸チオールエチルエステル & "I & 33 & 49 & - \\
\hline ラウリン酸チオールペンジルエステル注 1 & 90 & 21 & 50 & 5 \\
\hline ステアリン酸チオールエチルエステル注 1 & $" \prime$ & 32 & 51 & 10 \\
\hline ステアリン酸チオールベンジルエステル注 2 & 95 & 20 & 54 & 14 \\
\hline
\end{tabular}

ラネーニツケル $10 \mathrm{~g}$, 反応時間 $2 \mathrm{hr}$, 反応温度 $30 \sim 35^{\circ} \mathrm{C}$, チオール酸エステル $0.009 \mathrm{~mol}$ 。 注 $180 \%$ アルコールには不溶である。

注 $295 \%$ ア ルコールでも難溶性であるだ反応温度を $40 \sim 45^{\circ} \mathrm{C}$ とした。
表 4 ラウリン酸チオールベンジルエステル〔A]和よび エチルエステル〔B〕の脱硫還元分解

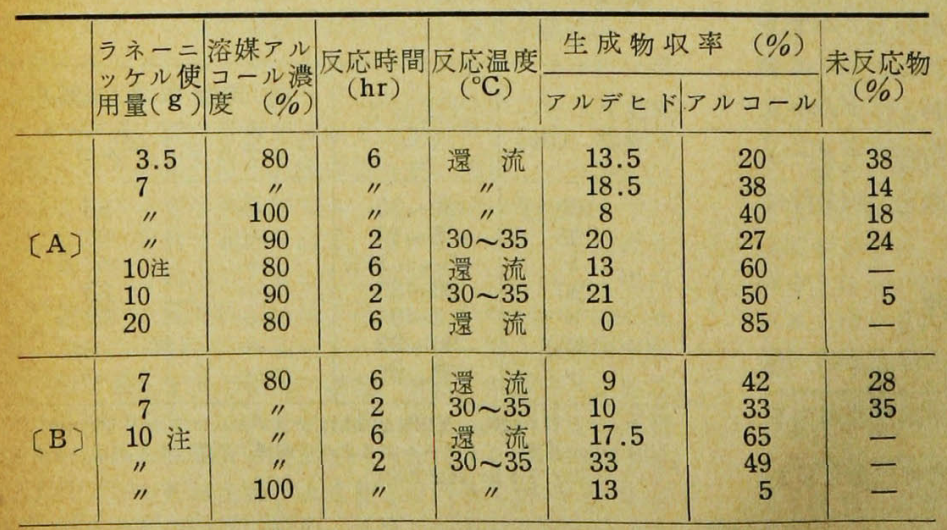

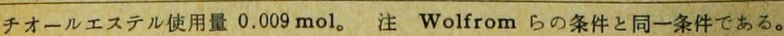

のラネーニッケルの量は前記アルコー ル生成条件の場合の半量に相当する。

次にこの条件下における二,三の高 級脂肪族チオール酸ベンジルエステル とエチルエステルの還元分解反応の結 果を表 5 亿示した。

どの場合に颃いても還元生成物の収 率およびアルデヒドの収率はベンジル エステルよりもエチルエステルを原料 とした場合が高い。

従来ラネーニッケルによる還元分解 機構には Hauptmann らフ) (ジスルフ 1ドおよびチオールエステル) および 三井ら ${ }^{8)}($ エーテルおよびトシルエス 
テル類）の数多くの報告がみられるが殊に後者は立体化 学的な立場より還元分解機構を究明して興味ある結果を 得ている。いずれとおいても反応の第 1 段階として官能 基の触媒上への吸着がとり上けられている。このチオー ル酸エステルの還元分解においても同一過程をたどり，

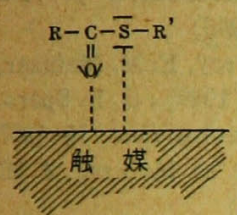

図 1
図 1 のようにカルボニル基 の酸素とチオエーテル基のイ オウに拝触媒上への吸着 が問題になる。このさいR'に 電子吸引性のベンジル基をつ けたものは電子放出珄のエチ ル基の場合より同一条件で還元生成物の収量の低下する ことは前者に比して後者のイオウにおける電子密度が高 くなり，したがって触媒上への吸着が容易になるためと 考えられる。これは第 2 報におけるジカルボン酸モノチ オールエステルの還元分解結果によっても支持される。

\section{III. 実 験 $の$ 部}

\section{1. チオール酸エステルの合成}

a 法) Jeger ${ }^{3)}$ 法にしたがい縮合剈としてはピコリ ンを用いた。

b 法) $1.5 \sim 1.7 \mathrm{~mol}$ のメルカプタンを $1.5 \mathrm{~mol}$ の 30\% カセイソーダ溶液に溶解し，これに酸塩化物 $1 \mathrm{~mol} の$ 10〜20\%ベンゼン溶液を水冷下にかくはんしながら滴下 する。滴下終れば $2 \mathrm{hr}$ かくはえを続け 1 夜放置後反応
混液を水，5\%力セイソーダ溶液，5\%硫酸溶液,水の順 で洗い，無水硫酸ナトリウムで乾燥後溶媒を去り残留物 を蒸留または再結晶法（アルコールより）によって精製 した。これらの反応結果および分析值を表 6 に示した。

2. ラネーニッケルの展開法 川上研究所ラネー N. D. を $20 \%$ カイソーダ溶液 $60^{\circ} \mathrm{C}$ で $50 \mathrm{~min}$ を要 して展開し ${ }^{10)}$, フェノールフタレイン中性まで水洗後ア ルコールで洗浄し，ついで反応溶媒におきかえる。

\section{3. チオール酸エステルの脱硫還元分解法}

i. 常温にて反応させる場合はラネーニッケルを20 $30 \mathrm{cc}$ の溶媒に懸垂し，強くまぜながらチオールエステ ルの 3〜 5\%溶液 (上記溶媒使用) を加え，さらに規定 時間までかくはんし，ただちにラネーニッケルをロ去す る。

ii. 還流下で反応させる場合は i としたがい，チオ ールエステルを加えたのちただちに規定時間まで還流す る。

\section{IV. 生成物の処理}

1. アルコール生成の場合＼cjkstart還元液を減圧濃縮後エ 一テルに溶解し， $5 \%$ ๖ソーダ溶液， $5 \%$ 塩酸，水 の順で洗い, 粗アルコールを得た。この粗アルコール分 中にイオウは全く認められない。

2. アルデヒド生成の場合 常法により溶媒の大半 を留去後（原料が結晶の場合はこの濃縮に少量のアルコ

表 6

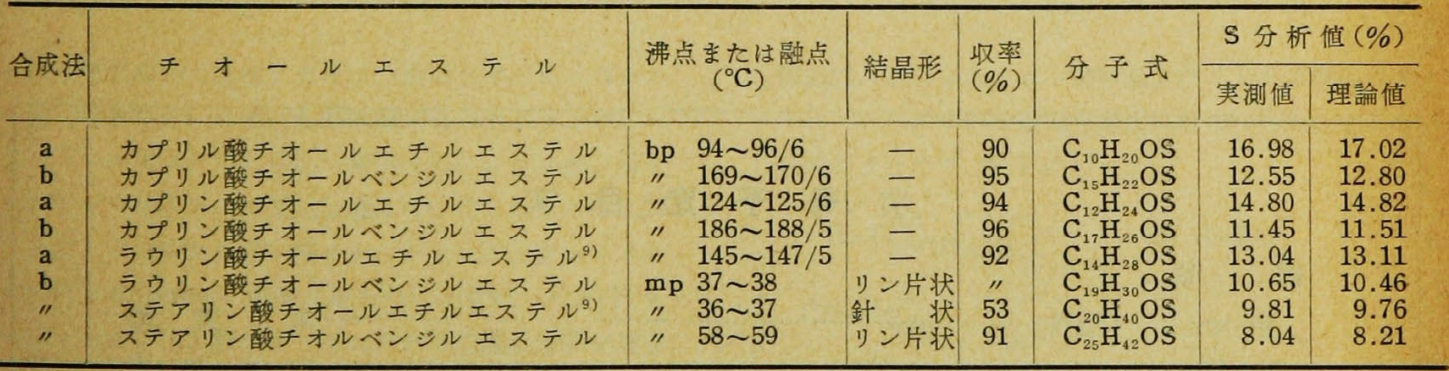

表 7

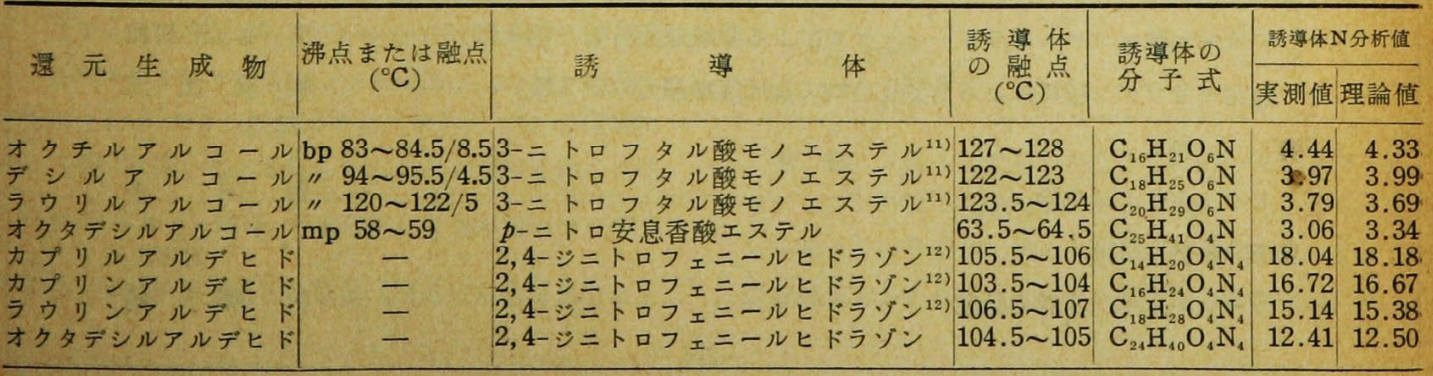


一ルを加えて冷却すると未反応物が析出する)エーテル 飞溶解し，飽和酸性亜硫酸ソーダ溶液でアルデヒドを付 加物として分離し，残存するアルコール性生成物拓よび 未反応物の混合物の溶液は $20 \%$ カセイカリ溶液で 加水 分解し，未反応物をカルボン酸として除去し，アルコー ル性生成物を分取する。

\section{V. 生成物の確認}

以上のごとく分離したアルコール性生成物は蒸留した 後結晶性エステルとして確認する。アルデヒドの酸性亜 硫酸ソーダ付加物は炭酸ガス気流中で 5 \%硫酸で加水分

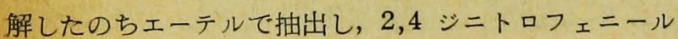
ヒドラゾンとして確認する。その結果および分析值を 表7飞示した。

$$
\text { 文献 }
$$

1) M L. Wolfrom, J. V. Karabinos, J. Am. Chem. Soc. 66909 (1944); S. Berustein, L. Dorfman, ibid. 681152 (1946) ; R. B. Woodward, W. J. Brehm; ibid. 702107 (1948); E. Mosettig, Org. Reaction \& 229 (1954); H. Adkins, A. A. Pavlic, J. Am. Chem. Soc. 69 3039 (1947)
2) J. Bougault, E. Cattelain, P. Chabrier, Bull. Soc. Chim. 7781 (1940)

3) O. Jeger, J. Norymberski, S. Szpilfogel, V. Prelog, Helv. Chim. Acta 29684 (1946); V. Prelog. J. Narymberski, O. Jeger, ibid. 29360 (1946)

4) M. L. Wolfrom, J. V. Karabinos, J. Am. Chem. Soc. 68 724, 1455 (1946)

5) A. V. Mc Intosh, A. M. Searcy, E. M. Meinzer, R. H. Levin, ibid. 713317 (1949) ; G. B. Spero, A. V. Mc Intosh, R. H. Levin, ibid. 701907 (1948) ; A. V. Mc Intosh, E. M. Meinzer, R. H. Lovin, ibid. 702955 (1948)

6) L. Mozingo, D. E. Wolf, S. Harris, K. Folker, J. Am. Chem. Soc. 651013 (1943)

7) H. Hauptmann, B. Wladislaw, Ann. 57645 (1952); J. Am. Chem. Soc. 72710 (1950)

8) 三井, 今泉, 日化誌 771516 (1956), 三井, 今 泉, 熊谷, 山岸, 日化誌 791432 (1958)

9) A. W. Ralston, E. W. Segelrecht, J. Org. Chem. 4502 (1939)

10）和井田，安村，無機有機合成法II集 p. 1

11) G. M. Dickinson, Leo H. Grosson, J. E. Copenhaver, J. Am. Chem. Soc. 591094 (1937)

12) Charles F. H. Allen, J. Am. Chem. Soc. 52 2957 (1930)

\section{次号予 定 目 次}

総説

$$
\begin{aligned}
& \text { 絧ーパラジウム触媒 } \\
& \text { 化学工業に持けるオートメーション……………............................ 竹 中 治 夫 }
\end{aligned}
$$$$
\text { 報文 }
$$$$
\text { チオール酸エステルのラネーニッケルによる脱硫還元分解（第 } 3 \text { 報） }
$$
奥 村, 增 村他 硫化モリブデン触媒による有機化合物の加圧接触還元（第 3 報） 板 橋 国夫 资

資 料 ヒダントインの化学 角 田 勤

業界情勢

プラスチックス業界の話題 